\title{
肛門管癌の臨床病理学的検討
}

\begin{tabular}{llllll}
\multicolumn{5}{c}{ 国立がんセンター研究所病理部, 同 } & 病院外科* \\
林 & 賢 & 廣田 & 映五 & 板橋 & 正幸 \\
北條 & 慶一* & 森谷 & 冝皓* & 沢田 & 俊夫*
\end{tabular}

\section{CLINICOPATHOLOGICAL STUDIES OF ANAL CANAL CANCER}

\author{
Ken HAYASHI, Teruyuki HIROTA, Masayuki ITABASHI, \\ Keiichi HOJO*, Yoshihiro MORIYA* and Toshio SAWADA* \\ Pathology Division, National Cancer Center Research Institute \\ Department of Surgery, National Cancer Center Hospital*
}

過去25年間に切除された肛門管癌55例を組織型および占居部位（雬状線を境界に上部群，下部群に 分類）を中心に臨床病理学的に検討した。腺癌 24 例では75\%が上部群で扁平上皮癌14例, 粘液癌13例 ではそれぞれ64\%，69\%が下部群であった。リンパ節転移は $44 \%$ ，単径リンパ節転移は24\%であり， 粘液癌はリンパ節転移 $23 \%$ と低率で，下部群は単径リンパ節転移 $32 \%$ と高率であった。 5 年生存率は 組織型別では粘液癌 $(67 \%)$ が腺癌 $(52 \%)$ 扁平上皮癌 $(42 \%)$ 上り良好であり，占居部位別では上 部群（66\%）が下部群（33\%）上り有意に良好であった。遠隔成績，単径リンパ節転移状況からみて 肛門管癌を上部群と下部群に分類することは予後を判断する上に有用であると考えられた。

索引用語：肛門管癌, 肛門管癌の組織型別進展様式, 肛門管癌の単径リンパ節転移, 上部肛門管癌, 下部肛門管癌

\section{I. 緒 言}

肛門管は大腸癌取扱い規䄪1)では恥骨直腸筋付着部 上縁より肛門縁をでの管状部と規定されている。消化 管の最末端に位置し解剖学的には内外括約筋之肛門挙 笳により支えられ血管系，リンパ系，神経系も結腸， 直腸に比較し複雑な構造を有している。 また発生学的 にも内胚葉と外肧葉組織の接合部に当たっている，肛 門管上皮は口側の直腸粘膜上皮に連続する単層円柱上 皮から移行上皮さらには重層扁平上皮である肛門上皮 から構成されており, わずか数 $\mathrm{cm}$ の管空臓器ながら その組織形態は多彩である21 5)，そのため肛門管癌は 直腸癌と比較し症状, 肉眼形態, 組織型, 発育進展様

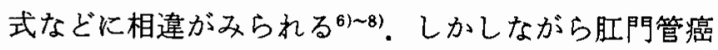
の発生頻度は直腸肛門管の癌の $2 \sim 5 \%$ と比較的まれ であり6) 9)その臨床像の報告はわが国ではいまだ少な い.今回われわれは肛門管原発癌の切除例を組織型と 歯状線を境界とした占居部位別分類を試み，臨床病理

\footnotetext{
$<1989$ 年 5 月 8 日受理>別刷請求先：林賢 テ104 中央区築地 5-1-1 国立がんセンターレ ジデントルーム 530 号
}

学的に検討したので報告する。

\section{II. 対象と方法}

1962年 5 月から1987年 9 月末すでに国立がんセン ターで切除された肛門管原発巣64例のうち同時性重複 癌 2 例, 覀性黒色腫 7 例を除く55例を対象とした。こ れらはいずれも組織学的に癌腫の中心が恥骨直腸筇付 着部より肛門側に位置するものであり同期間に切除さ れた全大腸癌1,961例, 直腸肛門癌1，134例のそれぞれ $2.8 \% ， 4.9 \%$ にある. 男女比は1.2対 1 で, 平均年齢 は61.5歳(34歳から85歳)であった。

手術術式は51例（93\%）に腹会陰式直腸切断術（う ち14例は周囲蔵器を合併切除)，2 例に骨盤内蔵全摘 術， 2 例に局所切除術が行われた。リンパ節郭清は48 例 $(87 \%)$ に $\mathrm{R}_{2}$ 以上の郭清が行われており 5 例は $\mathrm{R}_{1}$ で 2 例は $\mathrm{R}_{0}$ であった。 な 20 例 (36\%) に単径リンパ節 郭清が行われた（同時性または 1 か月以内17例，異時 性 3 例), 35例は絶対治癒切除, 19例は相対治瘺切除で 治癒切除率は98\%であり，1例（2\%）のみ局所の非 治㽽切除に終わったが肺, 肝, その他遠隔転移例はな かった。 
因 1 肛門管癌における占居部位の分類

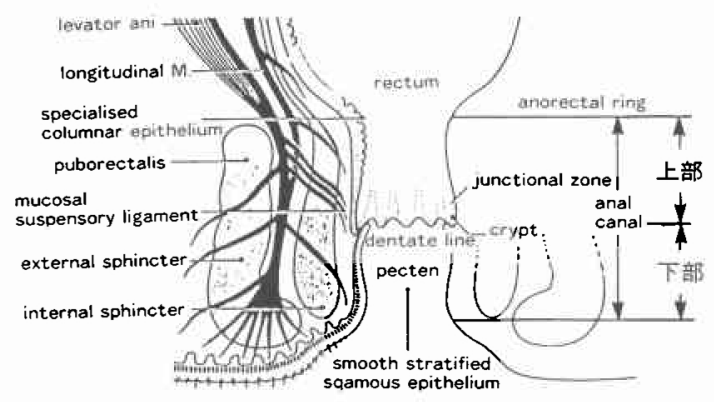

臨床病理学的事項は主として大腸癌取扱い規約 ${ }^{1}$ と 従った，組織型は腺癌(粘液癌を除く), 粘液癌, 扁平 上皮癌, その他（腺扁平上皮癌, 類基底細胞癌, 未分 化癌）に分類し，占居部位は歯状線を境界として腫瘍 の中心の位置により上部肛門管癌（以下，上部群とす る）と下部肛門管癌（以下，下部群とする）に分類し た (図 1).

また組織型別および占居部位別に肉眼形態, 壁深達 度, リンパ節転移, 腫瘍径, 腫腸環周率, Dukes 分類 を比較検討し，統計学的処理は $\chi^{2}$ 検定により行った。 さらに遠隔成績は Dukes 分類, 組織型, 占居部位別に Kaplan-Meier 法（以下 KM 法）および generalized Wilcoxon 法（以下 GW 法）を用い有意差検定を行っ た.

\section{III. 結 果}

1）組織型と占居部位

組織型別頻度は腺癌 24 例 $(43 \%)$ ，扁平上皮癌14例 (25\%)，粘液癌13例（24\%）の順であったが，稀な組 織型として腺扁平上皮癌 1 例，類基底細胞癌 1 例，未 分化癌 2 例を認めた，症例数の多かった腺癌, 扁平上 皮癌を高分化型，中分化型，低分化型に，末た粘液癌 を乳頭腺管型，印環細胞型に亜分類するといずれる分 化型（高, 中分化型, 乳頭腺管型）が高率であった。 占居部位は上部群30例 (55\%), 下部群25例 (45\%) と 上部群がやや多かった，畽場の占居部位と組織型の相 関をみると, 腺癌では上部群が $75 \%$ を占め, 扁平上皮 癌，粘液癌では下部群がそれぞれ64\%，69\% と高率で あった（表 1 )。

\section{2) 肉眼形態}

主病巣が管腔内方向に増殖する管内型と筋層から外 側方向に堌殖する管外型に分類すると, 肛門管癌全体 では管内型 (肉眼的分類の $0 \sim 4$ 型に相当する)は $69 \%$ で管外型(肉眼的分類の 5 型に相当する)は $31 \%$ あ゙あ
表 1 肛門管癌の組織型分類と占居部位

\begin{tabular}{|c|c|c|c|c|c|}
\hline \multirow{2}{*}{ 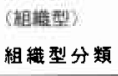 } & \multirow{2}{*}{\multicolumn{3}{|c|}{ 症例数 }} & \multicolumn{2}{|c|}{ 〈占居部位〉 } \\
\hline & & & & 上 部 & 下 部 \\
\hline 腺 & $24(43 \%)$ & $\begin{array}{l}\text { 高分化型 } \\
\text { 中分化型 } \\
\text { 低分化型 }\end{array}$ & $\begin{array}{r}18 \\
3 \\
3 \\
\end{array}$ & ${ }^{18}(75 \%)$ & ${ }^{6}(25 \%)$ \\
\hline 扁平上皮癌 & $14(25 \%)$ & $\begin{array}{l}\text { 高分化型 } \\
\text { 中分化型 } \\
\text { 低分化型 }\end{array}$ & $\begin{array}{l}6 \\
7 \\
1 \\
\end{array}$ & ${ }^{5}(36 \%)$ & $9_{(64 \%)}$ \\
\hline 粘 液 䅉 & $13(24 \%)$ & $\begin{array}{l}\text { 㲗頭腺管型 } \\
\text { 印環細胞型 }\end{array}$ & $\begin{array}{r}10 \\
3 \\
\end{array}$ & ${ }^{4}(31 \%)$ & $9_{(69 \%)}$ \\
\hline 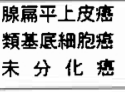 & $\begin{array}{l}1(2 \%) \\
1(2 \%) \\
2(4 \%)\end{array}$ & & & 3 & 1 \\
\hline 計 & $55(100 \%)$ & & & $30(55 \%)$ & $25(45 \%)$ \\
\hline
\end{tabular}

表 2 肛門管癌の組織型と占居部位別肉眼形態

\begin{tabular}{|c|c|c|c|c|c|c|c|c|c|c|c|c|}
\hline \multicolumn{5}{|c|}{ 〈組䳬型〉 } & \multicolumn{7}{|c|}{ （占居部位） } & \multirow[b]{2}{*}{ H } \\
\hline 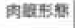 & 㙞 & 榬 再平 & 工场 & & 粘破琶 & & 他 & 上 & 部 & 下 & 部 & \\
\hline 0梨 & 3) & & 1) & & 1) & & 0 & $5)$ & & 0 & & $5\langle 94\}$ \\
\hline 1㓶 & 1 & & 1 & & 0 & & 0 & 1 & & 1 & & $2(4 \%)$ \\
\hline 2 梨 & 17 & 22 & 4 & 9 & 3 & 4 & 3 & 21 & 28 & 6 & 10 & $27\{49 \pi)$ \\
\hline 3型 & 1 & $(92 \%)$ & 3 & $(64 \%)$ & 0 & (31\%) & & 1 & (93\%) & 3 & $(40 \%)$ & $4(7 \times)$ \\
\hline 4型 & o) & & 0 ) & & 01 & & 0 & 0 & & 0 & & $0(0.65)$ \\
\hline 5型 & 2 & $(8 \%)$ & 5 & $(36 \%)$ & 9 & $(69 \%)$ & & 2 & $(7 \%)$ & 15 & $(60 \%)$ & $17(3106)$ \\
\hline It & 24 & & 14 & 4 & 13 & & 4 & 30 & * & 25 & & $55(100 \mathrm{~W})$ \\
\hline
\end{tabular}

表 3 肛門管癌の組織型と占居部位別壁深達度

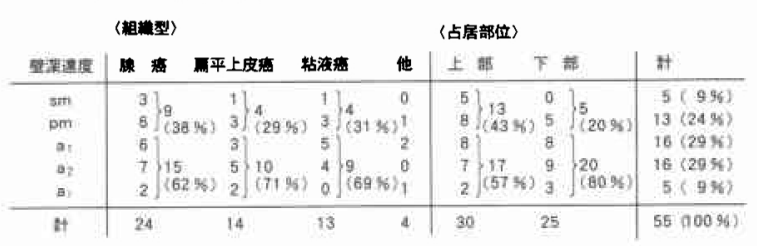

た，組織型別にみると腺癌は管内型が $92 \%$ と高率で中 でも限局潰瘍型（2 型）が71\%を占めた，扁平上皮癌 も管内型が $64 \%$ を占め限局潰瘍型 ( 2 型)，浸潤潰瘍型 ( 3 型)が高率であった。一方粘液癌では特殊型 ( 5 型) の管外型が $69 \%$ と有意に高率であった $(\mathrm{p}<0.01)$. ま た占居部位別にみると上部群では管内群が $93 \%$ を占め るのに対し，下部群では管外型が $60 \%$ と高率で両群間 に統計学的有意差を認めた $(\mathrm{p}<0.01)$ (表 2$)$.

3）壁深達度

次に組織学的壁深達度をみると全体では $\mathrm{m}$ は無く, sm $9 \%$, pm $24 \%, a_{1} 29 \%, a_{2} 29 \%$, ai $9 \%$ で $91 \%$ は進行癌であった，組織型別にみると腺癌で壁内にと どまる $\mathrm{sm}, \mathrm{pm}$ 症例が $38 \%$ とやや高率であった，占居 部位別にみると 5 例の $\mathrm{sm}$ 癌はすべて上部群に属し， $\mathrm{sm}, \mathrm{pm}$ 症例の比率は上部群 $43 \%$ に対し下部群 $20 \%$ と 上部群に高率であった（表 3 ).

4）リンパ節転移 
組織学的リンパ節転移をみると全体では転移率44\% であった，組織型別にみる転移率は腺癌 $50 \%$, 扁平上 皮癌 $43 \%$, 粘液癌 $23 \%$ で粘液癌は低率であった。 $\mathrm{n}_{2}$ の 15 症例のうち鼡径リンパ節転移を伴わないのは 3 例で, 5 例は傍直腸リンパ節（側方リンパ節）と単径リンパ 節転移を伴い，7 例は単径リンパ節転移のみであった。 $\mathrm{n}_{4}$ は 2 例でいずれも傍大動脈りンパ節転移（上方リン 節）陽性で腺癌の 1 例は䋃径リンパ節転移なく, 扁 平上皮癌の 1 例は同リンバ節に転移を認めた。占居部 位別にみると上部群は $47 \%$ ，下部群は $40 \%$ の転移率で 差を認めなかったが $\mathrm{n}_{2}$ 以上の転移症例は下部群に高 率であった，単径リンパ節転移をみると13例（全体の $24 \% ， リ ン ハ ゚$ 節転移陽性例の $54 \%$ ）に陽性であり， 6 例は上方あるいは側方リンパ節転移を伴い，7例は単 径リンパ節転移のみ認められた。組織型別にみると腺

表 4 肛門管癌の組織型と占居部位別リンパ節転移

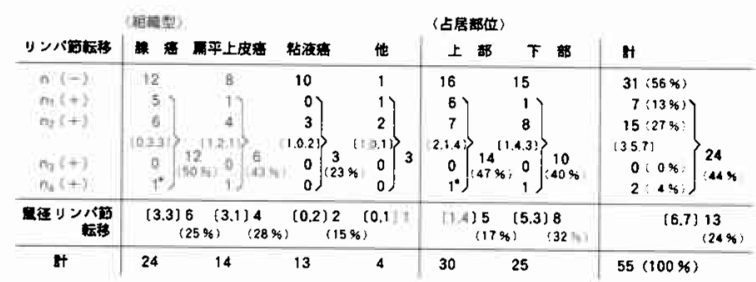

(注) $\mathrm{n}_{2}$ の[ ]内は上方・側方転移, 側方・鼠径リンパ 節転移, 鼠径リンパ節転移のみの症例数をあらわ す. $\mathrm{n}_{4} ・$ は鼠径リンパ節転移を併わず，無印は鼠径 リンパ節転移を併ら症例をあらわす。鼠径リンパ 節転移の〔]内は上方あるいは側方節転移と鼠 径リンパ節転移，臼径リンパ節転移のみの症例数 をあらわす。

表 5 肛門管癌における腫瘍径別の組織型と占居部位 の比較

\begin{tabular}{|c|c|c|c|c|c|c|c|}
\hline \multicolumn{3}{|c|}{ 〈組維型〉 } & \multicolumn{5}{|c|}{ (占居部位) } \\
\hline 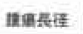 & 4t 堇 & 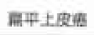 & 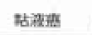 & fte & 上部 & 下 & 4 \\
\hline $4 \mathrm{~cm}$ 末謴 & $10(42 *)$ & $\theta(43 \%)$ & $4(314)$ & 1 & $16(53 x)$ & $4(164)$ & $20(36 \%)$ \\
\hline $4 \mathrm{~cm}$ 以上 & $14(58 \%)$ & $B(57 \%)$ & $9(6996)$ & 3 & $14(47 \pi)$ & $21(8456)$ & $35(64.96)$ \\
\hline it & 24 & 14 & 13 & 4 & 30 & 25 & $55(10096)$ \\
\hline
\end{tabular}

表 6 肛門管癌に拈ける腫瘍環周率別の組織型と占居 部位の比較

\begin{tabular}{|c|c|c|c|c|c|c|c|}
\hline \multicolumn{3}{|c|}{ 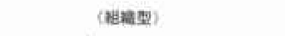 } & \multicolumn{5}{|c|}{ 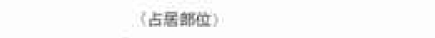 } \\
\hline 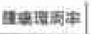 & 部 典 & 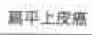 & 蛙满要 & it & 上䧈 & F 15 & H. \\
\hline 50 96. & g. (38\%) & $5\{36 \%\}$ & $4(31 \mathrm{k})$ & 0 & $14(47 \%)$ & $4(168)$ & $18(32 \%)$ \\
\hline $50 \times 15$ & $15\{62 \mathrm{~m}\rangle$ & $9(6455)$ & $9(699)$ & 4 & $16(5396)$ & $21(84 \%)$ & $37(67 \%)$ \\
\hline it & 24 & 14 & 13 & 4 & $30 \quad \cdots$ & 25 & $55(100 \%)$ \\
\hline & & & $\neq \neq 0<0$ & 0.05 & & & \\
\hline
\end{tabular}

癌 $25 \%$, 扁平上皮癌 $28 \%$ ，粘液癌 $15 \%$ と粘液癌で低率 で，占居部位別にみると上部群 $17 \%$ に対し下部群 $32 \%$ と下部群に高率であった（表 4 ）。

またリンパ節転移の有無と壁深達度の相関をみると $\mathrm{sm}$ に転移はなく $\mathrm{pm} 31 \%, \mathrm{a}_{1} 50 \%, \mathrm{a}_{2} 50 \%$, ai $80 \%$ と深達度が増すほど転移率は増加した。

5）腫場長径, 環周率

平均腫場径は $4.7 \pm 2.0$ (平均 $\pm \mathrm{SD}$ ) $\mathrm{cm}$, 平均環周率 は $54 \pm 23$ (平均 $\pm \mathrm{SD}$ )\%であった。症例を腫湟径 $4 \mathrm{~cm}$ 末 満群と $4 \mathrm{~cm}$ 以上群, 周率を $50 \%$ 未満群 分け組織型, 占居部位を比較した。全体では腫湯径 $4 \mathrm{~cm}$ 以上, 畽湯環周率 $50 \%$ 以上が $67 \%$ を占め, 組織型別に みると各組織型とも腫瘍径 $4 \mathrm{~cm}$ 以上かつ腫漡環周率 $50 \%$ 以上群が過半を占めたが特に粘液癌でその傾向が 顕著であった，占居部位別では下部群が上部群より腫 堭径 $(p<0.01)$, 環周率 $(p<0.05)$ とも有意に大きかっ た（表 5,6).

6) 組織学的進行程度 (Dukes 分類)

全体では Dukes A 20\%, Dukes B 36\%, Dukes C 44\%であり組織型でみると粘液癌でDukes C が低率 であった. 占居部位別にみると Dukes A は上部群 $30 \%$ に対し下部群 $8 \%$ と, 下部群で有意に低率であった

表 7 肛門管癌の組織型と占居部位別組穖学的進行度 (Dukes 分類)

\begin{tabular}{|c|c|c|c|c|c|c|c|}
\hline \multicolumn{3}{|c|}{ 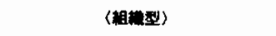 } & \multicolumn{5}{|c|}{ 〈占居部位〉 } \\
\hline Dukses 개게 & 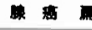 & 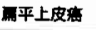 & 跕设变 & 㨁 & 上 部 & 下 部 & H \\
\hline Dukes A & $5(21 \%)$ & $2(14 \%)$ & $3(23 \%)$ & 1 & $9(30 \%)$ & $2(8 \%)$ & 11 (20\%) \\
\hline Dukes B & $7(29 \%)$ & $6(43 \%)$ & $7(54 \%)$ & 0 & $7\left(23^{*} \%\right)$ & $13(52 \%)$ & $20(36 \%)$ \\
\hline Dukes C & $12(50 \%)$ & $6(43 \%)$ & $3(23 \%)$ & 3 & $14(47 \%)$ & $10(40 \%)$ & $24(44 \%)$ \\
\hline It & 24 & 14 & 13 & 4 & 30 & 25 & $55(100 \%)$ \\
\hline
\end{tabular}

図 2 肛門管癌の Dukes 分類別生存曲線

(Kaplan-Meier 法)

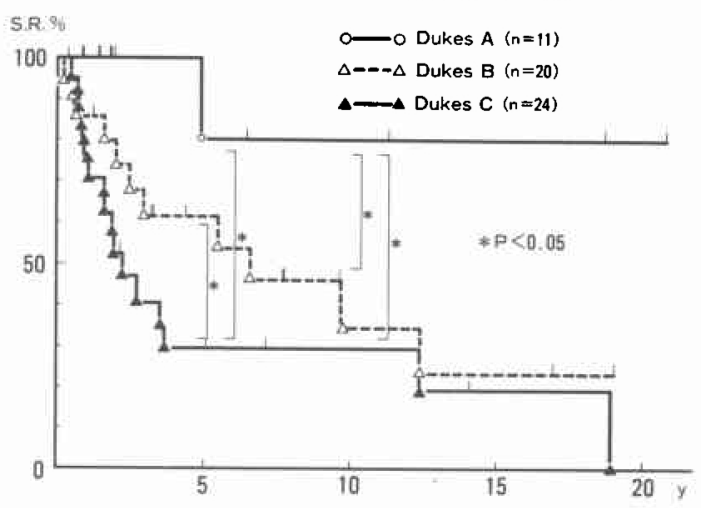


図 3 肛門管癌の組織型別生存曲線

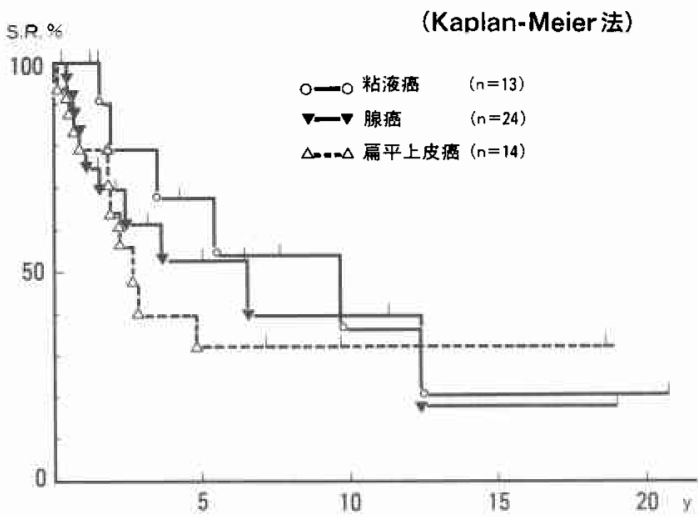

図 4 分化型肚門管癌の組織型別生存曲線

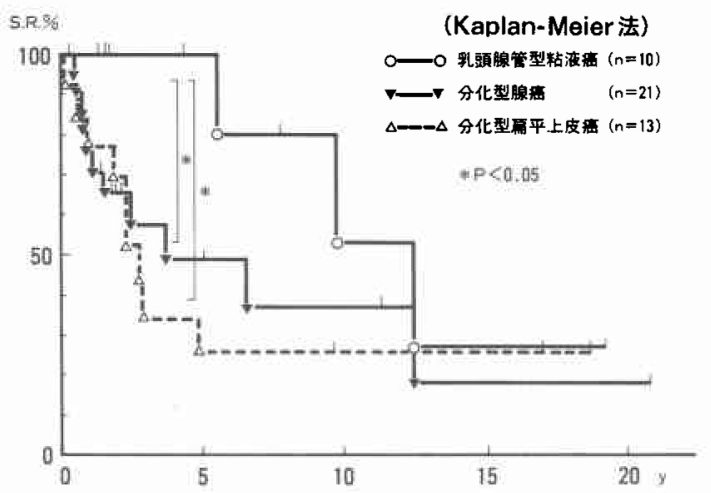

$(\mathrm{p}<0.05)($ 表 7$)$.

7）遠隔成績

肛門管癌治癒切除例全体では 5 年生存率は $49.8 \%$ で あった。 5 年生存率をDukes 分類別にみると Dukes A 80\%, Dukes B 62\%, Dukes C 29\%と特に Dukes $\mathrm{C}$ で低率であった(KM 法*に拈いて $\mathrm{p}<0.05, \mathrm{GW}$ 法 Dukes A と Dukes C間で $\mathrm{p}<0.05$ )（図 2).

組織型別にみると 5 年生存率は粘液癌 $67 \%$, 腺癌 $52 \%$, 扁平上皮癌 $42 \%$ と粘液癌で良い傾向であったが 統計学的有意差を認めなかった(図 3)。しかし分化型 癌 (乳頭腺管型粘液癌と高, 中分化型腺癌ならびに扁 平上皮癌) のみで 5 年生存率を比較すると粘液癌は腺 癌, 扁平上皮癌より有意に成績良好であった（KM 法, $\mathrm{p}<0.05$ ) (図 4).

一方占居部位別にみると 5 年生存率, 10 年生存率は

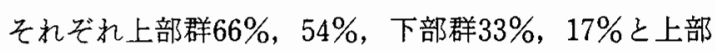
群で有意に成績良好であった（KM 法*に沶いて $\mathrm{p}<$ $0.05, \mathrm{GW}$ 法, $\mathrm{p}<0.05$ ）（図 5 ）. さらに占居部位と
図 5 肛門管癌の占居部位別生存曲線

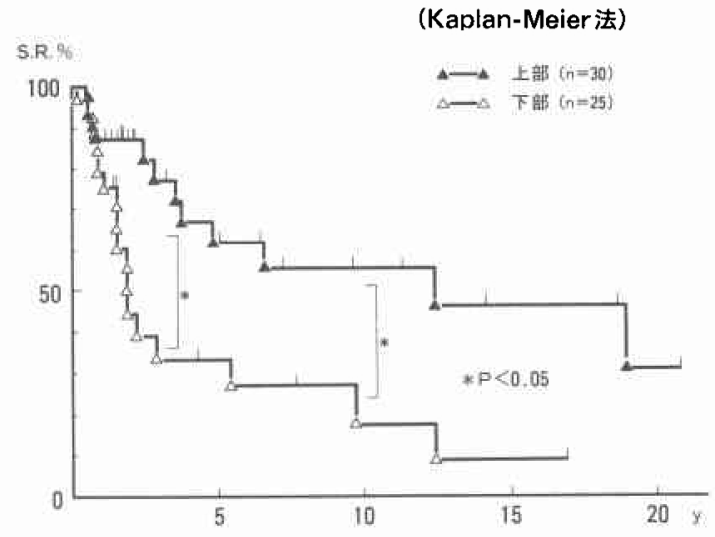

図 6 肛門管癌の Dukes 分類と占居部位別生存曲線

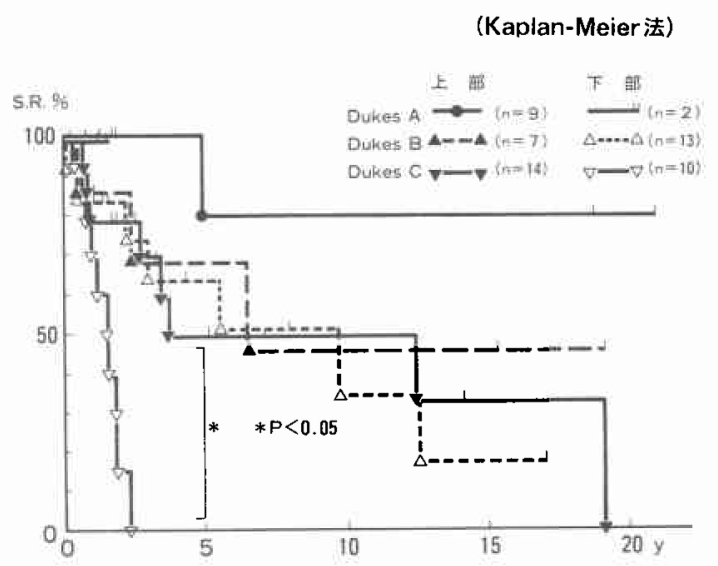

Dukes 分類の関係をみるとDukes A, Dukes B では差 がなかったが，Dukes Cでは 5 年生存率が上部群 $49 \%$ に対し下部群 $0 \%$ と統計学的に有意差を認めた（GW 法, $\mathrm{p}<0.05$ ) (図6).

\section{IV. 考察}

近年診断技術の進歩や検診の普及に伴い, 比較的早

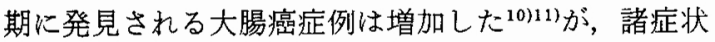
を有しながら痔などの良性疾患と誤診されやすいた め，肛門管癌ではいまだ早期癌が比較的少ないのが現 状である12).

欧米では扁平上皮癌や類基底細胞癌のみを肛門管癌 として報告しているものが多い(6)8113)15)が，わが国では 大腸癌取扱い規約作成により以前は歯状線より上部の 腺癌は直腸癌として扱われていたが, 恥骨直腸筋付着 部上縁より下部に癌の中心があるあのを組織型を問わ ず肛門管癌と定義されるに至った1)16)21). 
肛門管癌は大腸癌取扱い規約では主として肉眼的検 查の段階で決定されるとしている11. しかし恥骨直腸 筋付着部上縮は肛門指䛦では容易に触知しらるが切除 標本では粘膜側からでは判断しがたい。高進行した 肛門管癌では下部直腸癌との鑑別の困難な症例も少な からず経験される。この混乱を回避するため今回の検 討は恥骨直腸笳付着部を組織学的に確認し腫場の中心 がそれより肛門側に位置するものを対象とした。ただ 乙部分切除術例など恥骨直腸筋の明らかでないるのは 肛門管原発之確認できた症例のみを対象に含めた。

高野 ${ }^{22)}$ の測定によると邦人の恥骨直腸筋付着部上縁 より肛門縁までの長さは平均 $3.0 \mathrm{~cm}$, 歯状線より肛門 縁までの長さは平均 $1.8 \mathrm{~cm}$ である。肛門管癌はこの短 いが解剖学的, 組織学的に複雑な部位を発生母地とす るため組織像は多彩である10).

組織型では腺癌 $(44 \%)$, 扁平上皮癌 $(25 \%)$, 粘液 癌 $(24 \%)$ ) 順に多く, 腺扁平上皮癌, 類基底細胞癌, 未分化癌などはまれな組織型であった。本邦諸家の報 告では腺癌は37.5から $57.5 \%$ ，粘液癌は17から30\%, 扁平上皮癌は 9.5 から $20 \%$ の頻度であり今回の検討で は扁平上皮癌が比較的高率であった ${ }^{16) 20}$.

これらの組織型と発生母地には密接な関係がある。 最も高頻度であった腺癌は上部群が $75 \%$ と高率で、こ れらは高分化癌では管内型が多く単層円柱上皮由来の

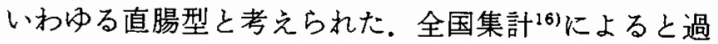
半数が直腸型腺癌で今回の検討より高率であるがこれ は対象および肛門管癌の判定の基準による違いと考党 られた。腺癌の5ち下部群 6 例 (29\%) の中には部分 的に粘液産生の見られるすのが 3 例含まれ腺癌から粘 液癌の移行を示唆する所見と考兄られた。

扁平上皮癌ではわれわれがすでに報告したよう $に^{5)}$ ，部分的に角化の顕著な高分化型と角化の乏しい 中分化型が活添同率に認められた。この扁平上皮癌の 中には重層扁平上皮由来之考学られる下部群ばかりで なく上部群にも5 例 (36\%) 認められた. Morson ら ${ }^{23)}$ は歯状線より上部の扁平上皮癌は移行上皮に起源する としており藤原ら ${ }^{199}$ は管内型発育を示す症例が多いこ とよりこれを支持している。 今回の対象の中で Mor. son らの説を支持した例は腫演下縁が歯状線より口側 に位置した深達度 $\mathrm{pm}$ の 1 例のみで, 他の扁平上皮癌 の上部群では缠瘍下縁が歯状線を越えた進行癌であり 移行上皮由来か扁平上皮由来か示唆する所見は得られ なかった。

粘液癌の組織発生については種々の議論があり
Kay $ら^{24)}$ は肛門腺, Dukes ら ${ }^{25}$ は重複腸管の残存上 皮, Morson ら ${ }^{26)}$ は移行上皮由来としている。今回の検 討では粘液癌は下部群, 管外型がそれぞれ $69 \%$ 之多数 を占め肛門腺との関係が示唆されたがそれを組織学的 に確認できたのは 2 例のみであった. Fenger ら 27は痔 瘦を伴う腺癌の粘液染色により肛門腺由来か直腸粘膜 由来か鑑別が可能であると報告しているが，藤原ら ${ }^{19)}$ はCulling の染色 ${ }^{281}$ 用い追試を行って否定的な結果 を出している，今回われわれもCullingの染色を試み たが肛門腺, 直腸粘膜由来の鑑別は不可能であった。

組織学的壁深達度は pm 以上の進行癌が $91 \%$ を占め たが組織型による差は認められなかった。また下部群 は全例進行癌であり $a_{1} \sim a i$ 頻度も $80 \%$ と上部群よ り進展した症例が多かった。 また腫瘍径, 環周率は組 織型でみると粘液癌が大きく占居部位でみると下部群 が有意に大きかった。

全症例のリンパ節転移率は $44 \%$ 之本邦諸家の報告と ほぼ同率であり深達度が深くなる潘ど高率であっ た ${ }^{16) 201299}$ 。組織型でみると粘液癌で低率であったが占 居部位別には差が認められなかった。また今回の検討 では単径リンパ節転移は下部群に $32 \%$ と高率であった

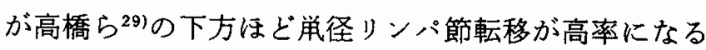
といら報告と一致するものであった。

肚門管癌の遠隔成績を大腸癌と比較すると朋門管癌 治瘾切除例の 5 年生存率は $49.8 \%$ と大腸癌治㾤切除例 (71.2\%)より不良であった ${ }^{10}$. 肛門管癌を Dukes 分類 別にみると 5 年生存率は Dukes A, Dukes B と比較し て Dukes Cで有意に不良であった ( $\mathrm{GW}$ 法, $\mathrm{p}<0.05)$.

組織型で比較すると 5 年生存率の良いものから粘液 癌, 腺癌, 扁平上皮癌の順で特に分化型癌の比較では 粘液癌と腺癌および扁平上皮癌の間で有意差が認めら れた ( $\mathrm{KM}$ 法, $\mathrm{p}<0.05)$. 大腸癌の中では粘液癌の子 後が不良であるとの報告がある ${ }^{30311}$ が，肛門管原発の 粘液癌では乳頭腺管型が10例と多く，この型ではリン パ節転移が認められなかったため, むしろ良好な生存 率が得られたと考えられた。一方印環細胞型粘液癌で は 3 例ともリンパ節転移 $\left(\mathrm{n}_{2}\right)$ を伴い全例 4 年以内に死 亡した。

また占居部位別にみると下部群が上部群に比較し有 意に成績不良であった $(G W$ 法, $\mathrm{p}<0.05)$ ，下部群に は組織型では予後良好な粘液癌の頻度が高いわけであ るが予後不良な扁平上皮癌も多く, また腫瘍径, 環周 率は大きく, 壁深達度は深く, 組織学的進行度では Dukes A が低率で, Dukes Cの中でも単径リンパ節転 
移を含め $\mathrm{n}_{2}$ 以上の症例が高率であることなどに依拠 しているものと考兄られた。

今回の検討では組織型により占居部位, 肉眼形態, リンパ節転移率などに差がみられ手術成績にも相違が 認められた。すた上部群と下部群の比較でも組織型, 肉眼形態, 単径リンパ節転移率, 腫湯径ならびに環周 率に差がみられ, 上部群に比べ下部群は進行癌が多く， 有意に成績不良であるといら結果が得られた。

組織型に注意をはらい, 占居部位を上部群，下部群 に分類し診断評価することは生物学的特性や予後を判 断する上に有用であると考兄られた。

\section{V. 結 論}

肛門管癌切除の 55 例を臨床病理学的に検討し以下の 結論を得た。

1）組織型は腺癌 $44 \%$, 扁平上皮癌 $25 \%$, 粘液癌 $24 \%$ の順に多く, 腺癌で上部群が $75 \%$, 扁平上皮癌, 粘液 癌で下部群がそれぞれ64\%，69\%と高率であった，

2）肉眼型では腺癌は限局潰瘍型を中心とした管内 型が $92 \%$ と高率で，扁平上皮癌でも管内型が $64 \%$ を占 めたが，粘液癌では特殊型の管外型が $69 \%$ と高率で あった $(\mathrm{p}<0.01)$.

3）リンパ節転移率は $44 \%$ で粘液癌に $23 \%$ と低率で あったが，上部群，下部群による差を認めなかった。 また単径リンパ節転移は $24 \%$ \%吕り下部群に $32 \%$ と高 率であった。

4）腫㵿径, 環周率は粘液癌で大さい傾向があり, た腫場径 $4 \mathrm{~cm}$ 以上の症例は下部群では $84 \%$ を占め上 部群 $(47 \%)$ 上り有意に高率であった $(\mathrm{p}<0.01)$.

5) 組織型別の 5 年生存率は良好なもの上り粘液癌 (67\%), 腺癌 (52\%), 扁平上皮癌 (42\%) の順であり， 特に分化型癌の比較では粘液癌が有意に成績良好で あった $(\mathrm{p}<0.05)$.

6）占居部位別の 5 年生存率は上部群 $66 \%$, 下部群 $33 \%$ で部群で有意に成績良好であった $(\mathrm{p}<0.05)$.

\section{文献}

1）大腸癌研究会編：大晹癌取扱い規約. 金原出版, 東 京, 1985

2) Goliger JC: Surgery of the Anns Rectum and Colon 5th ed. Bailliere, Tindall, London, 1984, p1-47

3) Hollinshead WH: Embryology and anatomy of the anal canal and rectum. Dis Colon Rectum $5: 18-22,1961$

4）鬼束惇哉：肛門管の解剖。外科治療 22 ： 150-157, 1970
5）北條慶一, 廣田映五, 佐野量造汪か：肛門部癌悪性 腫場の検討。外科 $35: 705-712,1973$

6) Grinnell RS : An analysis of fortynine cases of squamous cell carcinoma of the anus. Surg Gynecol Obstet 98 : 29-39, 1954

7) Bacon $\mathrm{HE}$ : Cancer of the colon and anal canal. Lippincott, Philadelphia, 1964, p332-379

8) Boman BM, Moertel CG, O'connell MJ et al: Carcinoma of the anal canal. Cancer 54 : 114-125, 1984

9) Papillon J : Rectal and anal cancers. Springer-Verlag, New York, 1982, p145-177

10）北條慶一：大腸癌治療成績の向上と今後の課題. 手術 38:557-569, 1984

11）森谷冝皓, 菊池史郎：肛門・直腸癌の早期䛦断。外 科診療 $28: 435-440,1986$

12）北條慶一, 廣田映五, 小山靖夫ほか：肛門部癌悪性 腫場。日本大腸肛門病会誌 $2: 314-320,1973$

13) Greenall MJ, Quan SHG, Urmacher $C$ et al: Treatment of epidermoid carcinoma of the anal canal. Surg Gynecol Obstet 161 : 509-517, 1985

14) Beahrs OH, Wilson SM: Carcinoma of the anus. Ann Surg $184: 422-428,1976$

15) Golden GT, Horsley SJ: Surgical management of epidermoid carcinoma of the anus. Va Med Mon 101:661-664, 1974

16）隅越幸男：肛門癌に関するアンケート調查報告. 日本大腸肛門病会誌 $35: 92-97,1981$

17）有輪六郎：肛門癌の病理. 日本大腸肛門病会誌 $34: 494-499,1981$

18）隅越幸男, 岡田光生, 住江正治注か：肛門癌の病 理. 胃之腸 $12: 317-325,1977$

19）藤原 章, 吉田正一, 加藤 洋: 肛門管癌の病理. 胃之腸 $22 ： 279-290,1987$

20）奥野匡宥, 池原照幸, 長山正義注か：肛門癌の臨床 的検討一自験例25例を中心に一日臨外医会誌 $48: 1079-1084,1987$

21）小山靖夫, 森谷冝皓, 北條慶一：肛門癌の臨床, 日 本大腸肛門病会誌 $34: 479-484,1981$

22）高野正博：肚門管の定義とその測定値。日本大腸 肛門病会誌 $31: 226-229,1978$

23) Kay S: Mucoepidermoid carcinoma of the anal canal and relation to the anal duct. Cancer $7: 359-366,1954$

24) Dukes CE, Galvin C: Colloid carcinoma arising within fistulae in the anorectal region. Ann R Coll Surg Engl 18 : 246-261, 1956

25) Morson BC, Volkstadt H: Muco-epidermoid tumors of the anal canal. J Clin Pathol 16: 200-205, 1962

26) Fenger C, Filipe MI: Pathology of the anal glands with special reference to their mucin 
histochemistry. Acta Pathol Microbiol Scand A $85: 273-285,1979$

27) Culling CFA, Reid PE, Dunn WL: A new histochemical method for the identification and visualization of both side chain acylated and nonacylated sialic acids. J Histochem Cytochem $24: 1225-1230,1976$

28) Morson BC, Dawson IMP: Gastrointestinal pathology 2nd ed, Blackwell, Oxford, 1979, p741
$-756$

29）高橋 孝, 古島 毫, 太田博俊ほか：䀴門癌リンパ 節転移の特徵一とくに鼠径リンパ節について一。 日本大腸肛門病会誌 $34: 473-478,1981$

30）弥政晋輔, 厝田映五, 板橋正幸はか：大腸粘液癌の 臨床病理学的検討. 日消外会誌 $21: 75-81,1988$

31）奥野匡宥, 池原照幸, 長山正義ほか：大腸粘液癌の 臨床病理学的特徵. 日臨外医会誌 $48: 609-614$, 1987 